An Official Publication of Association of Pharmacy Professionals

REVIEW ARTICLE

\title{
ROLE OF LIRAGLUTIDE IN A MAJOR COMPLiCATION OF Diabetes: A Critical Review of Clinical STUdies
}

Gaurav Gupta ${ }^{1 *}$, Rajiv Dahiya ${ }^{2}$, Mahaveer Singh ${ }^{1}$, Juhi Tiwari ${ }^{1}$, Sushil Kumar Sah ${ }^{3}$, Madhu Ashwathanarayana $^{4}$, Gopala Krishna ${ }^{5}$ and Kamal Dua ${ }^{6,7}$

${ }^{1}$ Department of Pharmacology, School of Pharmaceutical Sciences, Jaipur National University, Jagatpura, Jaipur-302017, Rajasthan, India

${ }^{2}$ Laboratory of Peptide Research and Development, School of Pharmacy, Faculty of Medical Sciences, The University of the West Indies, St. Augustine, Trinidad \& Tobago, West Indies

${ }^{3}$ Birat Medical College, Tankisinuwari-56613, Biratnagar, Nepal

${ }^{4}$ East West College of Pharmacy, Vishwaneedam Bangalore-560091, Karnataka, India

${ }^{5}$ Department of Pharmacology, A.M Reddy Memorial College of Pharmacy, Narasaraopet-522601, Guntur, Andhra Pradesh, India

${ }^{6}$ Discipline of Pharmacy, Graduate School of Health, University of Technology Sydney, Ultimo, New South Wales-2007, Australia

${ }^{7}$ School of Biomedical Sciences and Pharmacy, The University of Newcastle, Callaghan, New South Wales2308, Australia \& Priority Research Centre for Healthy Lungs, Hunter Medical Research Institute, Newcastle, New South Wales-2305, Australia

${ }^{*}$ E-mail: gauravpharma25@gmail.com

Tel.: +91 7014790412

Received: Mar 30, 2018 / Revised: Apr 29, 2018 / Accepted: Apr 30, 2018

Diabetes is a most common, serious and chronic illness resultant from the error of insulin secretions or action. Liraglutide is a synthetic glucagon-like peptide-1 receptor agonist (GLP-1 RA) that shares $\mathbf{9 7 \%}$ of homology with the glucagon-like peptide-1 (GLP-1) human structure. It acquires a muchextended circulating half-life. Including of numerous in-vitro and in vivo studies explaining the liraglutide efficiency on diabetes, however, various preclinical and clinical studies representing the potential benefit of liraglutide in other complicated diseases induced by diabetes. The therapeutic conclusion of liraglutide in association with other difficulties generated in diabetic patients is complex and includes numerous positive roles. So, there is a necessity of clinical studies to clarify the roles of liraglutide in other complications caused by diabetes. In the coming time, liraglutide uses lonely or in combination may be the predictable approach in the successful management of other diabetes tempted complications. The aim of this review is to collect evidence on the real-world clinical efficiency of liraglutide on main diseases created by diabetes. In present study, results from electronically searchable data are included from randomized clinical studies, cohort studies, clinical trials in addition to other related articles.

Key words: Diabetes, Retinopathy, Nephropathy, Neuropathy, Liraglutide, Clinical studies.

\section{INTRODUCTION}

Diabetes is a most common disease represented by the elevated level of blood glucose caused by insufficient insulin secretion and/or insulin action in the pancreatic $\beta$ cells (Sharma et al 2017). According to the report of International Diabetes Federation (IDF) in 2013, 382 million individuals were affected by diabetes in all 
around the world and this number will raise up to more than 592 million by the year 2025 (Chellappan et al 2017). The main consequence of diabetes is the weakening of the body's ability to use food as either the insulin not properly producing by the pancreas or the body cannot accurately use insulin (American Diabetes, 2009).

The lower level of blood glucose (Hypoglycemia) is most frequently observed in patients with diabetes when the body gets too much insulin, very less food, a late meal, or more than the normal amount of exercise. Whereas when the body gets less amount of insulin, a higher quantity of food, or very little exercise, it outcomes in elevated levels of blood glucose (hyperglycemia) (Kazmi et al 2012).

Hyperglycemia may also have contributed to stress. Diabetes is primarily classified into three categories: type- 1 diabetes mellitus (T1DM), type-2 diabetes mellitus (T2DM) and gestational diabetes mellitus (GDM). T1DM, also called as insulin-dependent diabetes mellitus (IDDM), or "juvenile diabetes" reveals the autoimmune disorder and destruction of the pancreatic $\beta$ cells which further leads to the suppression or termination of insulin production (Khadra et al 2011). T2DM, also termed as non-insulindependent diabetes mellitus (NIDDM) or adultonset diabetes which is triggered by either lower level or absence of insulin resistance to insulin (King, 2012). T2DM is the more widespread form and responsible for $90 \%$ of all diabetes cases globally (Brunton, 2008).

Insulin resistance-related with obesity because of free fatty acids (FFA) and inflammatory cytokines released from the expanded adipose tissue (Guilherme et al 2008). GDM arises in around $7 \%$ cases of pregnancies and there is a bigger risk of morbidity and death to mother, fetus as well as a successive neonate. Special care and therapy are essential for GDM (Buchanan et al 2012). Women with the history of GDM have a suggestively higher risk of T2DM and of cardiovascular disease (CVD) during the following years after delivery (Kim, 2014; Herath et al 2017).

\section{Glucagon-like peptide-1 (GLP-1)}

Literature reports indicates that natural and synthetic peptides are associated with a wide spectrum of pharmacological properties (Greenwood et al 2011; Dahiya, 2007; 2008; Dahiya and Kumar, 2008; Dahiya and Gautam, 2011; Dahiya and Singh, 2017; Dahiya et al
2017). GLP-1RA are a novel class of anti-diabetic medicines that imitate the incretin hormones effects (Gupta et al 2017). Incretin hormone synthesizes in response to intake of food, GLP-1 can trigger insulin secretion by $\beta$-cells of the pancreas in a glucose-dependent way in addition to repress release of glucagon from $\alpha 2$-cells (Kim and Egan, 2008). GLP-1 receptors are mediating the action of GLP-1 in the maintenance of glucose homeostasis. Even though there is a number of potentially beneficial effects of GLP-1, however, it is inappropriate as a therapy in T2DM because of its short half-life (Nadkarni et al 2014).

\section{Liraglutide}

Liraglutide is a synthetic GLP-1RA which shares 97\% homology with the GLP-1 structure of human and retains an extended circulating halflife (Figure 1).

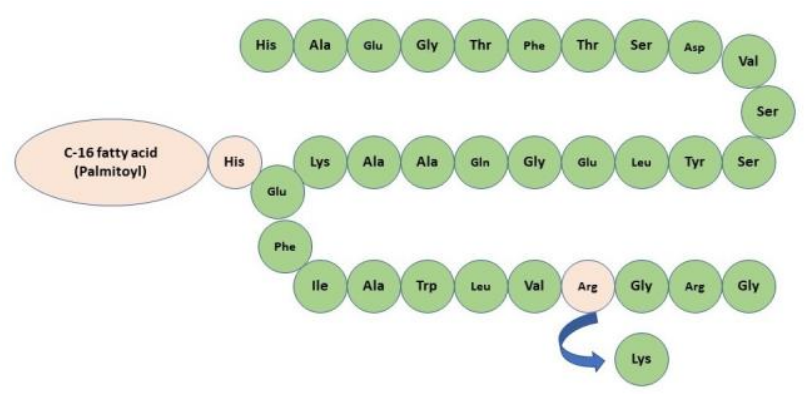

Fig. 1. Structural formula of liraglutide

It has prolonged pharmacokinetics as a consequence of accumulation at its site of injection, albumin binds in the circulation results in decreased susceptibility to degradation of enzyme, thus making it a new anti-diabetic therapy appropriate for once a daily injection subcutaneously (Tiwari et al 2017). Liraglutide has a potential of glucose-lowering effects across $24 \mathrm{~h}$, with perfections in fasting as well as postprandial glucose levels (Christensen et al 2011).

In clinical studies, liraglutide as a monotherapy has attained $\mathrm{HbA1c}$ reductions up to $1.6 \%$ in drug-naive subjects. The occurrence of hypoglycemia with the treatment of liraglutide is comparatively little, possibly reflecting a glucose addiction of its insulintropic action (Peters, 2013). Clinically liraglutide also has effects on body weight, along with mean decreases of 2-4 $\mathrm{kg}$ occurring in a big number of clinical trials (Schwartz and Kohl, 2010).

Moreover, facts are signifying positive effects on cardiovascular risk factors such as systolic blood 
pressure is decreased by $2-6 \mathrm{mmHg}$ with therapy of liraglutide, whereas Phase II clinical studies have proved molecular markers improvements of cardiovascular risk (Tiwari et al 2017). Liraglutide therapy also seems to have positive effects on pancreatic $\beta$-cell function, with clinical data viewing $\beta$-cell function improvements as well as capacity of insulin secretion (Garber, 2011).

\section{Literature search methodology}

The main aim of the present study is to review the literature on liraglutide and its clinical studies in diabetic patients in the last 10 years (2007 to 2017). Various databases such as science direct, pubmed, google scholar, and clinicaltrials.gov were used to explore for original articles and clinical trials available in the english language with the following keywords in combination "liraglutide", "retinopathy", "nephropathy", "neuropathy", "cardiovascular problems" and "diabetes". To date, the published clinical trials have studied the liraglutide effects on diabetes caused complications (Table 1).

Table 1. Clinical trials to investigate the effect of liraglutide alone or in combination in various conditions in diabetes

\begin{tabular}{|c|c|c|c|c|c|c|c|}
\hline Identifier no. & $\begin{array}{l}\text { Dose of } \\
\text { liraglutide }\end{array}$ & $\begin{array}{c}\text { Observing } \\
\text { effect }\end{array}$ & Duration & $\begin{array}{c}\text { Number } \\
\text { of } \\
\text { patients }\end{array}$ & Phase & $\begin{array}{l}\text { Year } \\
\text { started }\end{array}$ & Country \\
\hline NCT01208012 & $\begin{array}{l}0.6,1.2 \text { and } \\
1.8 \mathrm{mg}\end{array}$ & $\begin{array}{l}\text { Endothelial function } \\
\text { and microvascular } \\
\text { blood flow }\end{array}$ & 12 weeks & 44 & 4 & 2010 & Germany \\
\hline NCT01499108 & $\begin{array}{l}0.6,1.2 \text {, and } \\
1.8 \mathrm{mg}\end{array}$ & $\begin{array}{l}\text { Blood pressure } \\
\text { lowering effect }\end{array}$ & 49 days & 32 & 4 & 2011 & Denmark \\
\hline NCT01593137 & $1.8 \mathrm{mg}$ & $\begin{array}{c}\text { Clinical, endothelial } \\
\text { and image markers } \\
\text { of cardiovascular } \\
\text { risk }\end{array}$ & 12 months & - & 4 & 2012 & Spain \\
\hline NCT00620282 & $1.8 \mathrm{mg}$ & Endothelial function & 12 weeks & - & 3 & 2008 & $\begin{array}{l}\text { United } \\
\text { States }\end{array}$ \\
\hline NCT01511692 & $1.8 \mathrm{mg}$ & Appetite & 4 weeks & 43 & 1 & 2012 & Germany \\
\hline NCT01753362 & $1.8 \mathrm{mg}$ & Overweight & 26 weeks & 84 & 3 & 2012 & $\begin{array}{l}\text { United } \\
\text { States }\end{array}$ \\
\hline NCT01620489 & $1.8 \mathrm{mg}$ & $\begin{array}{l}\text { Moderate renal } \\
\text { impairment }\end{array}$ & 26 weeks & 279 & 3 & 2012 & $\begin{array}{l}\text { United } \\
\text { States }\end{array}$ \\
\hline NCT02109315 & $6.0 \mathrm{mg}$ & $\begin{array}{c}\text { Hypoglycemia-induced } \\
\text { oxidative stress, } \\
\text { inflammation and } \\
\text { endothelial } \\
\text { dysfunction }\end{array}$ & 8 weeks & 20 & 1 & 2014 & Spain \\
\hline NCT02201550 & $1.8 \mathrm{mg}$ & $\begin{array}{c}\text { Immune cells in } \\
\text { obese }\end{array}$ & 12 weeks & 9 & 1 & 2014 & Denmark \\
\hline NCT01179048 & $1.8 \mathrm{mg}$ & $\begin{array}{l}\text { Cardiovascular } \\
\text { outcome }\end{array}$ & 90 days & 9340 & 3 & 2010 & $\begin{array}{l}\text { United } \\
\text { States }\end{array}$ \\
\hline NCT02686177 & $1.2 \mathrm{mg}$ & Angiogenesis & 4 weeks & 40 & 4 & 2016 & France \\
\hline NCT01784965 & $\begin{array}{l}0.6,1.2 \text {, and } \\
1.8 \mathrm{mg}\end{array}$ & $\begin{array}{l}\text { Calorie restricted } \\
\text { diet augments } \\
\text { weight loss }\end{array}$ & 14 weeks & 69 & 3 & 2009 & $\begin{array}{l}\text { United } \\
\text { States }\end{array}$ \\
\hline NCT01595789 & $\begin{array}{l}0.6,1.2 \text {, and } \\
1.8 \mathrm{mg}\end{array}$ & $\begin{array}{c}\text { Coronary artery } \\
\text { disease }\end{array}$ & 26 weeks & 41 & 4 & 2012 & Denmark \\
\hline
\end{tabular}




\begin{tabular}{|c|c|c|c|c|c|c|c|}
\hline NCT00993304 & $\begin{array}{l}0.6,1.2 \text {, and } \\
1.8 \mathrm{mg}\end{array}$ & $\begin{array}{l}\text { Blood triglyceride } \\
\text { (fat) levels }\end{array}$ & 12 weeks & 20 & 1 & 2009 & Denmark \\
\hline NCT02655770 & $1.8 \mathrm{mg}$ & $\begin{array}{c}\text { Diastolic } \\
\text { dysfunction on } \\
\text { cardiac mri }\end{array}$ & 18 weeks & 40 & 4 & 2016 & Denmark \\
\hline NCT01399645 & $\begin{array}{c}0.6,1.2 \text {, and } \\
1.8 \mathrm{mg}\end{array}$ & Liver fat fraction & 12 weeks & 35 & 2 & 2011 & Canada \\
\hline NCT01785043 & $\begin{array}{c}0.6,1.2 \text {, and } \\
1.8 \mathrm{mg}\end{array}$ & Endothelial function & 3 months & 13 & 4 & 2013 & Spain \\
\hline NCT01425580 & $1.8 \mathrm{mg}$ & Heart failure & 18 weeks & 62 & 2 & 2012 & Sweden \\
\hline NCT02721888 & $1.2 \mathrm{mg}$ & $\begin{array}{l}\text { Fatty liver content } \\
\text { and lipoprotein } \\
\text { metabolism }\end{array}$ & 6 months & 120 & 4 & 2012 & France \\
\hline NCT02138045 & $\begin{array}{c}0.6,1.2 \text {, and } \\
1.8 \mathrm{mg}\end{array}$ & Diabetic neuropathy & 26 weeks & 40 & 1 & 2014 & Denmark \\
\hline NCT01394341 & $1.8 \mathrm{mg}$ & $\begin{array}{l}\text { Severe renal } \\
\text { insufficiency }\end{array}$ & 12 weeks & 40 & 4 & 2011 & Denmark \\
\hline NCT01761318 & $\begin{array}{l}0.6,1.2 \text {, and } \\
1.8 \mathrm{mg}\end{array}$ & $\begin{array}{l}\text { Cardiovascular } \\
\text { endpoints }\end{array}$ & 26 weeks & 50 & 4 & 2013 & $\begin{array}{l}\text { Netherlan } \\
\text { ds }\end{array}$ \\
\hline NCT01740921 & $1.8 \mathrm{mg}$ & $\begin{array}{l}\text { Microvascular } \\
\text { function }\end{array}$ & 4 months & 39 & - & 2011 & $\begin{array}{l}\text { United } \\
\text { Kingdom }\end{array}$ \\
\hline NCT01664676 & $1.2 \mathrm{mg}$ & Kidney function & 15 hours & 11 & 4 & 2012 & Denmark \\
\hline NCT03260881 & $\begin{array}{l}0.6,1.2 \text {, and } \\
1.8 \mathrm{mg}\end{array}$ & $\begin{array}{c}\text { Epicardial fat } \\
\text { inflammatory genes }\end{array}$ & 12 weeks & 40 & 4 & 2017 & $\begin{array}{l}\text { United } \\
\text { States }\end{array}$ \\
\hline NCT01931982 & $1.8 \mathrm{mg}$ & $\begin{array}{c}\text { Microvascular } \\
\text { myocardial function }\end{array}$ & 10 weeks & 20 & 4 & 2013 & Denmark \\
\hline NCT01755572 & $\begin{array}{l}0.6,1.2 \text {, and } \\
1.8 \mathrm{mg}\end{array}$ & $\begin{array}{c}\text { Blood pressure } \\
\text { outcomes }\end{array}$ & 21 days & 22 & 4 & 2013 & Canada \\
\hline NCT01472640 & $1.8 \mathrm{mg}$ & $\begin{array}{l}\text { Left ventricular } \\
\text { function in chronic } \\
\text { heart failure }\end{array}$ & 24 weeks & 240 & - & 2011 & Denmark \\
\hline NCT02963922 & $3.0 \mathrm{mg}$ & $\begin{array}{l}\text { Overweight or } \\
\text { obesity }\end{array}$ & 56 weeks & 400 & 3 & 2017 & $\begin{array}{l}\text { United } \\
\text { States }\end{array}$ \\
\hline NCT01272232 & $\begin{array}{l}1.8 \mathrm{mg} \text { and } \\
3.0 \mathrm{mg}\end{array}$ & $\begin{array}{l}\text { Overweight or } \\
\text { obese }\end{array}$ & 56 weeks & 846 & 3 & 2011 & $\begin{array}{l}\text { United } \\
\text { States }\end{array}$ \\
\hline NCT01847313 & $0.6 \mathrm{mg}$ & $\begin{array}{c}\text { Diabetic kidney } \\
\text { disease }\end{array}$ & 26 weeks & 20 & 3 & 2013 & Ireland \\
\hline NCT02147925 & $\begin{array}{c}0.6,1.2 \text {, and } \\
1.8 \mathrm{mg}\end{array}$ & Liver fat & 26 weeks & 150 & 4 & 2014 & China \\
\hline
\end{tabular}

Website: ClinicalTrials.gov

\section{Complications of diabetes and liraglutide}

Diabetes is associated with many complications. Acute metabolic problems are related with mortality such as diabetic ketoacidosis from the extremely high level of blood glucose concentrations (hyperglycemia) and coma as the consequence of the low level of blood glucose (hypoglycemia) (Kitabchi et al 2009). The subsequent complications are grouped under "microvascular disease" (due to injury to small blood vessels) and "macrovascular disease" (due to injury to the arteries) (Martín-Timón et al 
2014). Microvascular difficulties include neural damage (neuropathy), eye disease (retinopathy) and kidney disease (nephropathy) which are deliberated in detail later inside this review (Cade, 2008).

The most important macrovascular problems include accelerated CVD resultant in myocardial infarction and cerebrovascular disease revealing as strokes (Long and Dagogo-Jack, 2011). Even though the underlying etiology remnants controversial, there is also myocardial dysfunction related to diabetes which looks at least in part to be independent of atherosclerosis. Other chronic complications of diabetes include dementia, depression and sexual dysfunction (Laakso, 2010).

\section{Diabetic retinopathy}

Diabetic retinopathy is the common reason of sightlessness in adults (Liew et al 2014). After 20 years diagnosis, approximately all T1DM patients and at least $60 \%$ of T2DM patients will show indication of retinopathy (Lee et al 2015). This visual loss has a reflective negative impact on the patient's lives (Coyne et al 2004). According to the previously reported studies, slight or insignificant visual weakening is also linked with poor quality of life (Murchison et al 2017). The primary stages of retinopathy are considered by improved vascular permeability which develops to ischemia and retinal microvasculature neovascularization (Zhang et al 2011). Randomized controlled trials have revealed that carefully maintenance of nearregular glycemia and strict blood pressure control may contribute significantly towards reducing the diabetic retinopathy progression (Frank, 2004). Numbers of preclinical and clinical studies suggested a potential protective role for GLP-1RA in diabetic retinopathy (Salcedo et al 2012).

Based on earlier preclinical studies reports, it was elucidated that GLP-1 and longer-lasting protease-resistant analogs cross the blood-brain barrier (BBB) and show a neuroprotective effect in the various mouse models of numerous neurodegenerative diseases, such as Alzheimer disease, Parkinson disease etc. Based on the preclinical literature, it has been planned to observe the expression of liraglutide in human and $\mathrm{db} / \mathrm{db}$ mice retinas. They have systemic and topically administer (eye drops) GLP-1R agonists in $\mathrm{db} / \mathrm{db}$ mice and human then found the abundant expression of GLP-1R in the retinas from $\mathrm{db} / \mathrm{db}$ mice and human retina.
Furthermore, they have confirmed that systemic administration of a GLP-1R agonist (liraglutide) inhibits retinal neurodegeneration (glial activation, neural apoptosis, and electroretinographically abnormalities). These results could be associated with the substantial decrease in extracellular glutamate along with an increase of prosurvival signaling pathways (Hernandez et al 2016). A recent outcome of a clinical trial using a liraglutide (Liraglutide Effect and Action in Diabetes: Evaluation of Cardiovascular Outcome Results-A Long-Term Evaluation [LEADER]) in subjects with T2DM have presented that liraglutide reduced the diabetic retinopathy events than the placebo (Marso et al 2016). Though limited human studies propose a probable adverse effect of GLP-1 based treatments on retinopathy progression (PrasadReddy and Isaacs, 2015).

\section{Diabetic nephropathy}

Diabetic nephropathy is a main causing factor of chronic kidney disease, and presently the common reason of end-stage renal failure (Yuan et al 2017). Managing of diabetic patients with chronic kidney disease is more complex and economically more expensive than managing of patients with diabetes alone (Inzucchi et al 2012). Hyperperfusion and hyperfiltration of Glomerular are heralded the nephropathy onset, followed by leakage of albumin in urine (Albuminuria), and afterward development of renal failure (Dabla, 2010). Albuminuria is indicating a renal pathology and also its an independent marker of risk related to CVD (de Zeeuw, 2004). There is a further progression of cardiovascular risk of diabetic patients that reflects a reduction in the glomerular filtration rate (GFR) (Schneider et al 2016). Around every 3rd of diabetic patient develop substantial nephropathy, and the related pathophysiologic modifications in the renal system of these patients are heterogeneous and complex (Tan et al 2017). Poorly diabetic control, higher blood pressure, and genetic predisposition are related to progressive kidney disease because of diabetic nephropathy (Van Buren and Toto, 2011).

Many preclinical kinds of literature reported that that GLP-1RA bind to GLP-1 receptors in the kidney and have direct nephron protection through anti-apoptotic, antioxidant, and antiinflammatory, effects (Thomas, 2017; Li et al 2016). A retrospective study has included 84 Japanese T2DM patients diagnosed with overt 
nephropathy (stage 3 or 4), and from past 12 months had on liraglutide treatment. Body mass index, glycol albumin, estimated glomerular filtration rate, $\mathrm{HbA1c}$, and urine albumin-tocreatinine ratio was measured during a 6 and 12 months of liraglutide administration. They found a significant reduction in a level of HbA1c and glycol albumin and improvement in estimated glomerular filtration rate after administration of liraglutide compare to baseline. Based on results, they have concluded that liraglutide has a nephron protective activity from an early stage of nephropathy to the conservative stage of renal failure by improvement of weight loss or blood glucose (Tamasawa et al 2017). Another study was carried out to examine the effects on body mass index, glucose metabolism and kidney function of 18 diabetic nephropathy patients after 6 months administration of liraglutide. After 6 months of liraglutide administration, the blood glucose levels and average HbA1c were significantly reduced, though, no significant changes in kidney function. The outcomes suggested the improvement in glucose metabolism and body mass index reduction without observable changes in kidney function after administration of liraglutide to diabetic nephropathic patients (Ryuge et al 2012). In support of this study, it has been planned to study the effect of liraglutide on proteinuria and the progression of diabetic nephropathy in T2DM patients. They have included 23 T2DM patients with diabetic nephropathy, who had already been treated with renin-angiotensin system blockade under the restriction of dietary sodium. They were given a liraglutide to these selected patients for 48 weeks. After 48 weeks of administration of liraglutide, they have seen a significant reduction in a body mass index, HbA1c, and proteinuria as well as also a significant reduction in a rate of decline in estimated glomerular filtration rate whereas not observed any changes in systolic blood pressure. Based on results suggested that liraglutide treatment can be not only used for reducing the level of body mass index and HbA1c, but also for reducing the progression of nephropathy in T2DM patients (Imamura et al 2013).

One more clinical study performed in Japan decided to observe the hemodialysis effect on the blood glucose profile and level of liraglutide after administering liraglutide injection $0.6 \mathrm{mg}$ or $0.9 \mathrm{mg}$ ) in 10 Japanese T2DM patients with end-stage renal disease (ESRD). On day 1 and 3, hemodialysis was conducted which had not shown any significant changes in maximum plasma concentration, the area under the concentration-time curve, tmax of liraglutide in T2DM patients with ESRD.

Likewise, hemodialysis did not alter the duration of hyperglycemia and hypoglycemia, mean or minimum glucose levels following administration of liraglutide. Whereas, substantial rises in mean amplitude of glycemic excursions (MAGE) as well as standard deviation (SD) as markers of fluctuation in glucose value, and the maximum glucose level were detected during hemodialysis.

During hemodialysis, no side effects including a lower level of glucose were seen after the injection of liraglutide and it was well tolerated in T2DM patients with ESRD undergoing hemodialysis.

Based on results, researchers have recommended that hemodialysis did not disturb the pharmacokinetic profile of liraglutide, except for MAGE, SD, along with the maximum glucose level. Hence, it might be possible to use liraglutide therapy during hemodialysis in T2DM patients with ESRD. Without adjusting a dose (Osonoi et al 2014).

\section{Diabetic neuropathy}

$\mathrm{DM}$ is a common globally rising metabolic disease which is related with long-term complications of central nervous system (CNS) and peripheral nervous system (PNS) that results in nerves damage because of high level of blood sugar for a long period of time (Gogia and Rao, 2017). Peripheral, autonomic, proximal, and focal are the 4 types diabetic neuropathy, shows the symptoms of nerve damage such as tingling, numbness, pain in the toes, hands, legs, arms and fingers, indigestion, nausea or vomiting, dizziness and faintness due to drop in blood pressure as well as urination problem, dry vaginal in women and erectile dysfunction in men (American Diabetes Association, 2009).

Many kinds of literature reported a neuroprotective effect of GLP-1 analog, liraglutide in various neurodegenerative disorders in non-diabetic patients. Qi et al., group has induced an Alzheimer in a mice model through an amyloid $\beta$ protein $(A \beta)$ and observed an effect of liraglutide by administered with 25 nmol/day, liraglutide for 56 days. They found the significant effect of liraglutide by seen an alleviated cognitive impairment in $\mathrm{AD}$ through a reduction in phosphorylation of tau (Qi et al 2016). In addition to this, a study was conducted 
on a rat model of middle cerebral artery occlusion (MCAO) and given a liraglutide. They have discovered a significant decrease stressrelated hyperglycemia without causing hypoglycemia, reduced infarct volume, and improved neurologic deficits. On the basis of their observation, they concluded that liraglutide has therapeutic potential for patients with ischaemic stroke, particularly those with T2DM (Zhu et al 2016).

A number of studies have performed on the experimental animal which proved the neuroprotective activity of liraglutide such as anticonvulsant (Gupta et al 2017), antiparkinsonian (Athauda and Foltynie, 2017; Hansen et al 2016) in non-diabetic conditions. Only a clinical trial is going on to observe the effect of liraglutide on diabetic neuropathy. This trial was started in May 2014 and last updated on 22 April 2015 as per the US government website the clinicaltrial.gov. Purpose of this trial is to explore whether liraglutide has a long-term effect on clinical symptoms and biomarkers in patients with diabetic neuropathy (NIH).

\section{Cardiovascular diseases (CVD) associated with diabetes}

CVD is the major cause of illness and death in DM patients (Leon and Maddox, 2015). DM patients have a 3 to 5 times more risk of CVD and up to 3 times increase in death compared to nondiabetic persons (Fox, 2010). Diabetes, smoking, high body mass index, high cholesterol level (hypercholesterolemia), family history and age are the major risk factors for CVD such as atherosclerosis and coronary heart disease (CHD) (Daniels et al 2011). A high pulse pressure causes hardening of arteries which is an independent risk factor for CVD (Warren et al 2010). Few studies confirmed that the burden of risk factor tended to be more among women, with a larger incidence of obesity and trends toward more rates of diabetes mellitus, high blood pressure and home stress (Masic et al 2011). Apart from the major cardiac complications, other CVDs are also linked with DM patients such as disturbed conductibility of the left ventricle (LV) (Serhiyenko and Serhiyenko, 2015; Lauruschkat et al 2008), atrial fibrillation (AF) due to increased oxidant stress (OS) (Berry et al 2007). There is also evidence that high blood pressure might induce diabetic angiopathy through the OS generation or through the advanced glycation end products (AGEs) accumulation, leading to nitrous oxide systems (NOS) (Tabit et al 2010; Bertoluci et al 2015).

Based on the number of the reported literature of preclinical studies related to liraglutide effect on CVD in diabetes-induced experimental animals, has exhibited a significant protective effect. Inoue et al., group have observed an effect of liraglutide $(0.3 \mathrm{mg} / \mathrm{kg} ; \quad$ s.c. $/ 12 \mathrm{~h})$ in streptozotocin (STZ) induced a type 1 diabetes in rat's model. They were evaluated the lipid metabolism, apoptosis, genes that affect apoptosis, myocardial triglyceride, expression of protein kinase $\mathrm{C}$ (PKC). In the results, they found that protective effect of liraglutide via activation of the AMPK-Sirt1 pathway (Inoue et al 2015). In another study, liraglutide effect was seen on kidney fibrosis and atherosclerosis in a moderate uremia mouse model. They found a beneficial effect of liraglutide by reducing atherosclerosis and attenuating kidney inflammation (Bisgaard et al 2016).

Further, a clinical trial explored liraglutide effects on numerous cardio-metabolic risk markers of the metabolic syndrome in subjects with T2DM. They conducted an 18-month prospective and real-world study. All subjects had T2DM and the metabolic syndrome based on the American Heart Association and the National Heart Lung and Blood Institute (AHA/NHLBI) criteria. They included the 121 subjects with T2DM and the metabolic syndrome, naïve to incretin-based therapies and treated with metformin only. For the study, liraglutide $(1.2$ $\mathrm{mg} /$ day) was added to metformin (1500-3000 $\mathrm{mg} /$ day).

For metabolic parameters, fasting plasma samples were collected and thickness of carotidintima media was evaluated. They found a significant decrease in body mass index, waist circumference, HbA1c, fasting glycemia, triglycerides, total- and LDL-cholesterol, and carotid-intima media thickness throughout the 18-month follow-up. Correlation investigation presented a significant association among changes in triglycerides and carotid-intima media thickness. Hence, they proved that liraglutide improves cardio-metabolic risk factors in subjects with the carotid-intima media thickness in a real-world study (Rizzo et al 2016). In another eight months of prospective study, 29 subjects with T2DM and non-alcoholic fatty liver disease (NAFLD) were included. Liraglutide (0.6 mg/day; 14 days) followed by $1.2 \mathrm{mg} /$ day, was administered along with metformin. They have observed a significant 
reduction in a level of glycated hemoglobin in both groups. There were no observable changes in a lipid level, body weight, and waist circumference. Significant reduction in carotidintima media thickness in T2DM patients with NAFLD, but not in T2DM patients without NAFLD (Rizvi et al 2015).

In addition to this, the outcome of 48 weeks liraglutide therapy was assessed on major risk factors of CVD in 115 T2DM outpatients (55 women and 60 men), on therapy of antihypertensive, stable hypoglycemic, and lipidlowering drugs.

They observed a substantial decrease from baseline of fasting blood glucose levels, HbA1c, waist, total cholesterol, triglycerides, body weight circumference, non-HDL-C and LDLcholesterol, and significant increase in the level of HDL-cholesterol as well as a significant decrease in both systolic and diastolic blood. They finally concluded that 48 weeks of liraglutide therapy with continuing hypoglycemic therapy significantly improves all major risk factors related to CVD and decreases cardiometabolic risk (Russo et al 2015).

\section{REFERENCES}

American Diabetes Association. Diagnosis and classification of diabetes mellitus. Diabetes Care 2009;33(1):S62-9. [DOI: 10.2337/dc10-S062]

Athauda D, Foltynie T. Protective effects of the GLP-1 mimetic exendin-4 in Parkinson's disease. Neuro pharmacology 2017 (in press). [DOI: 10.1016/j.neuro pharm.2017.09.023]

Berry C, Tardif JC, Bourassa MG. Coronary heart disease in patients with diabetes: part I: recent advances in prevention and noninvasive management. J. Am. Coll. Cardiol. 2007;49(6):631-42. [DOI: 10.1016/j.jacc.2006.0 9.046]

Bertoluci MC, Cé GV, da Silva AM, Wainstein MV, Boff W, Puñales M. Endothelial dysfunction as a predictor of cardiovascular disease in type 1 diabetes. World J. Diabetes 2015;6(5):679-92. [DOI: 10.4239/wjd.v6.i5.679]

Bisgaard LS, Bosteen MH, Fink LN, Sorensen CM, Rosendahl A, Mogensen CK, Rasmussen SE, Rolin B, Nielsen LB, Pedersen TX. Liraglutide reduces both atherosclerosis and kidney inflammation in moderately uremic LDLr-/- mice. PLoS One 2016;11:e0168396. [DOI: 10.137 1/journal.pone.0168396]

Brunton SA. The changing shape of type 2 diabetes. Medscape J. Med. 2008;10(6):143. Buchanan TA, Xiang AH, Page KA. Gestational diabetes mellitus: risks and management during and after pregnancy. Nat. Rev. Endocrinol. 2012;8(11):639-49. [DOI: 10.1038/nrendo.20 12.96]

Cade WT. Diabetes-related microvascular and macrovascular diseases in the physical therapy setting. Phys. Ther. 2008;88(11):1322-35. [DOI: 10.2522/ptj.2008 0008]

Chellappan DK, Yenese Y, Wei CC, Gupta G. Nanotechnology and diabetic wound healing: a review. Endocr. Metab.

\section{CONCLUSION AND PERSPECTIVES}

Results from the reported literature clearly show that liraglutide applies pleiotropic effects on humans in addition to potential hypoglycemic activity. The therapeutic effect of liraglutide in a major complication induced by diabetes is complex and involves in various beneficial effects. Our review supports consideration of a modification to prescribing guidelines for liraglutide's usage to allow in diabetic patients associated with complications like retinopathy, nephropathy, neuropathy and cardiovascular diseases. Literature indicates that less number of the clinical study was conducted on the effect of liraglutide on neuropathic diseases. Although a number of animal studies have performed for observing the liraglutide effect on diabetic neuropathy and showed positive effects, however clinical studies are required to perform so that actual human data can be analyzed. Any novel extension of liraglutide use in diabetic patients will need to be accompanied by a suitable reduction in dosage amount and careful follow-up valuations of different main organ functions.

Immune Disord. Drug Targets 2017;17(2):87-95. [DOI: 10.2174/1871530317666170421121202]

Christensen M, Bagger JI, Vilsboll T, Knop FK. The alpha-cell as target for type 2 diabetes therapy. Rev. Diabet. Stud. 2011;8(3):369-81. [DOI: 10.1900/RDS.2011.8.369]

Coyne KS, Margolis MK, Kennedy-Martin T, Baker TM, Klein R, Paul MD, Revicki DA. The impact of diabetic retinopathy: perspectives from patient focus groups. Fam. Pract. 2004;21(4):447-53.

Dabla PK. Renal function in diabetic nephropathy. World J. Diabetes 2010;1(2):48-56. [DOI: 10.4239/wjd.v1.i2.48]

Dahiya R. Synthesis of a phenylalanine-rich peptide as potential anthelmintic and cytotoxic agent. Acta Pol. Pharm. 2007;64(6):509-16.

Dahiya R. Total synthesis and biological potential of psammosilenin A. Arch. Pharm. (Weinheim) 2008;341(8): 502-9. [DOI: 10.1002/ardp.200800006]

Dahiya R, Gautam H. Solution phase synthesis and bioevaluation of cordyheptapeptide B. Bull. Pharm. Res. 2011; 1(1):1-10.

Dahiya R, Kumar A. Synthetic and biological studies on a cyclopolypeptide of plant origin. J. Zhejiang Univ. Sci. B 2008;9(5):391-400. [DOI: 10.1631/jzus.B0720001]

Dahiya R, Singh S. Synthesis, characterization, and biological activity studies on fanlizhicyclopeptide A. Iran. J. Pharm. Res. 2017;16(3):1176-84.

Dahiya R, Singh S, Kaur K, Kaur R. Total synthesis of a natural cyclooligopeptide from fruits of sugar-apples. Bull. Pharm. Res. 2017;7(3):151. [DOI: 10.21276/bpr.2017.7. 3.4]

Daniels SR, Pratt CA, Hayman LL. Reduction of risk for cardiovascular disease in children and adolescents. Circulation 2011;124:1673-86. [DOI: 10.1161/CIRCULAT IONAHA.110.016170] 
de Zeeuw D. Albuminuria, not only a cardiovascular/renal risk marker, but also a target for treatment?. Kidney Int. 2004;66(92):S2-6. [DOI: 10.1111/j.1523-1755.2004.092 01.x]

Fox CS. Cardiovascular disease risk factors, type 2 diabetes mellitus, and the framingham heart study. Trends Cardiovas. Med. 2010;20(3):90-5. [DOI: 10.1016/j.tcm.20 10.08.001]

Frank RN. Diabetic retinopathy. New Engl. J. Med. 2004; 350(1):48-58. [DOI: 10.1056/NEJMra021678]

Garber AJ. Incretin effects on $\beta$-cell function, replication, and mass: the human perspective. Diabetes Care 2011; 34(2):S258-S63. [DOI: 10.2337/dc11-s230]

Gogia S, Rao CR. Prevalence and risk factors for peripheral neuropathy among type 2 diabetes mellitus patients at a tertiary care hospital in coastal Karnataka. Indian J. Endocrinol. Metab. 2017;21(5):665-9. [DOI: 10.4103/ijem. IJEM_43_17]

Greenwood HC, Bloom SR, Murphy KG. Peptides and their potential role in the treatment of diabetes and obesity. Rev. Diabet. Stud. 2011;8(3):355-68. [DOI: 10.1900/RDS. 2011.8.355]

Guilherme A, Virbasius JV, Puri V, Czech MP. Adipocyte dysfunctions linking obesity to insulin resistance and type 2 diabetes. Nat. Rev. Mol. Cell Biol. 2008;9(5):367-77. [DOI: 10.1038/nrm2391]

Gupta G, Dahiya R, Dua K, Chellappan DK, Tiwari J, Sharma GN, Singh SK, Mishra A, Sharma RK, Agrawal M. Anticonvulsant effect of liraglutide, GLP-1 agonist by averting a change in GABA and brain glutathione level on picrotoxin-induced seizures. Excli J. 2017;16:752-4. [DOI: 10.17179/excli2017-283]

Hansen HH, Fabricius K, Barkholt P, Mikkelsen JD, Jelsing J, Pyke C, Knudsen LB, Vrang N. Characterization of liraglutide, a glucagon-like peptide-1 (GLP-1) receptor agonist, in rat partial and full nigral 6-hydroxydopamine lesion models of Parkinson's disease. Brain Res. 2016; 1646:354-65. [DOI: 10.1016/j.brainres.2016.05.038]

Herath H, Herath R, Wickremasinghe R. Gestational diabetes mellitus and risk of type 2 diabetes 10 years after the index pregnancy in Sri Lankan women-A community based retrospective cohort study. PLoS One 2017;12(6):e0179647. [DOI: 10.1371/journal.pone.0179 647]

Hernandez C, Bogdanov P, Corraliza L, Garcia-Ramirez M, Sola-Adell C, Arranz JA, Arroba AI, Valverde AM, Simo R. Topical administration of GLP-1 receptor agonists prevents retinal neurodegeneration in experimental diabetes. Diabetes 2016;65(1):172-87. [DOI: 10.2337/db 15-0443]

Imamura S, Hirai K, Hirai A. The glucagon-like peptide-1 receptor agonist, liraglutide, attenuates the progression of overt diabetic nephropathy in type 2 diabetic patients. Tohoku J. Exp. Med. 2013;231(1):57-61. [DOI: 10.1620/tje m.231.57]

Inoue $\mathrm{T}$, Inoguchi $\mathrm{T}$, Sonoda $\mathrm{N}$, Hendarto $\mathrm{H}$, Makimura $\mathrm{H}$, Sasaki S, Yokomizo H, Fujimura Y, Miura D, Takayanagi R. GLP-1 analog liraglutide protects against cardiac steatosis, oxidative stress and apoptosis in streptozotocin-induced diabetic rats. Atherosclerosis 2015;240 (1):250-9. [DOI: 10.1016/j.atherosclerosis.2015.03.026]

Inzucchi SE, Bergenstal RM, Buse JB, Diamant M, Ferrannini E, Nauck M, Peters AL, Tsapas A, Wender R, Matthews DR. Management of hyperglycemia in type 2 diabetes: a patient-centered approach: position statement of the american diabetes association (ADA) and the european association for the study of diabetes (EASD). Diabetes Care 2012;35(6):1364-79. [DOI: 10.2337/dc12-0413]

Kazmi I, Rahman M, Afzal M, Gupta G, Saleem S, Afzal O, Shaharyar MA, Nautiyal U, Ahmed S, Anwar F. Antidiabetic potential of ursolic acid stearoyl glucoside: a new triterpenic gycosidic ester from Lantana camara. Fitoterapia 2012;83(1):142-6. [DOI: 10.1016/j.fitote.201 1.10.004]

Khadra A, Pietropaolo M, Nepom GT, Sherman A. Investigating the role of T-cell avidity and killing efficacy in relation to type 1 diabetes prediction. PLoS One 2011;6(5):e14796. [DOI: 10.1371/journal.pone.0014796]

Kim C. Maternal outcomes and follow-up after gestational diabetes mellitus. Diabet. Med. 2014;31(3):292-301. [DOI: 10.1111/dme.12382]

Kim W, Egan JM. The role of incretins in glucose homeostasis and diabetes treatment. Pharmacol. Rev. 2008;60(4):470-512. [DOI: 10.1124/pr.108.000604]

King AJ. The use of animal models in diabetes research. Br. J. Pharmacol. 2012;166(3):877-94. [DOI: 10.1111/j.1476-5 381.2012.01911.x]

Kitabchi AE, Umpierrez GE, Miles JM, Fisher JN. Hyperglycemic crises in adult patients with diabetes. Diabetes Care 2009;32(7):1335-43. [DOI: 10.2337/dc099032]

Laakso M. Cardiovascular disease in type 2 diabetes from population to man to mechanisms: the kelly west award lecture 2008. Diabetes Care 2010;33(2):442-9. [DOI: 10.2 337/dc09-0749]

Lauruschkat AH, Arnrich B, Albert AA, Walter JA, Amann B, Rosendahl UP, Alexander T, Ennker J. Diabetes mellitus as a risk factor for pulmonary complications after coronary bypass surgery. J. Thorac. Cardiovasc. Surg. 2008;135(5): 1047-53. [DOI: 10.1016/j.jtcvs.2007.07.066]

Lee R, Wong TY, Sabanayagam C. Epidemiology of diabetic retinopathy, diabetic macular edema and related vision loss. Eye Vis. (Lond) 2015;2:17. [DOI: 10.1186/s40662-01 5-0026-2]

Leon BM, Maddox TM. Diabetes and cardiovascular disease: epidemiology, biological mechanisms, treatment recommendations and future research. World J. Diabetes 2015;6(13):1246-58. [DOI: 10.4239/wjd.v6.i13.1246]

Li P-C, Liu L-F, Jou M-J, Wang H-K. The GLP-1 receptor agonists exendin-4 and liraglutide alleviate oxidative stress and cognitive and micturition deficits induced by middle cerebral artery occlusion in diabetic mice. $B M C$ Neurosci. 2016;17:37. [DOI: 10.1186/s12868-016-02729]

Liew G, Michaelides M, Bunce C. A comparison of the causes of blindness certifications in England and Wales in working age adults (16-64 years), 1999-2000 with 20092010. BMJ Open 2014;4(2):e004015. [DOI: 10.1136/bmj open-2013-004015]

Long AN, Dagogo-Jack S. The comorbidities of diabetes and hypertension: mechanisms and approach to target organ protection. J. Clin. Hypertens. (Greenwich) 2011;3(4):244-51. [DOI: 10.1111/j.1751-7176.2011.0043 4.x]

Marso SP, Daniels GH, Brown-Frandsen K, Kristensen P, Mann JF, Nauck MA, Nissen SE, Pocock S, Poulter NR, Ravn LS, Steinberg WM, Stockner M, Zinman B, Bergenstal RM, Buse JB. Liraglutide and cardiovascular outcomes in type 2 diabetes. N. Engl. J. Med. 2016;375(4):311-22. [DOI: 10.1 056/NEJMoa1603827]

Martín-Timón I, Sevillano-Collantes C, Segura-Galindo A, del Cañizo-Gómez FJ. Type 2 diabetes and cardiovascular 
disease: have all risk factors the same strength?. World J. Diabetes 2014;5(4):444-70. [DOI: 10.4239/wjd.v5.i4.444]

Masic I, Rahimic M, Dilic M, Kadribasic R, Toromanovic S. Socio-medical Characteristics of Coronary Disease in Bosnia and Herzegovina and the World. Mater. Sociomed. 2011;23(3):171-83.

Murchison AP, Hark L, Pizzi LT, Dai Y, Mayro EL, Storey PP, Leiby BE, Haller JA. Non-adherence to eye care in people with diabetes. BMJ Open Diabetes Res. Care 2017;5(1): e000333. [DOI: 10.1136/bmjdrc-2016-000333]

Nadkarni P, Chepurny OG, Holz GG. Regulation of glucose homeostasis by GLP-1. Prog. Mol. Biol. Transl. Sci. 2014; 121:23-65. [DOI: 10.1016/B978-0-12-800101-1.00002-8]

NIH. Clinical trial on treatment of diabetic neuropathy with liraglutide (TODINELI). Accessed 28/09/2017.

Osonoi T, Saito M, Tamasawa A, Ishida H, Tsujino D, Nishimura R, Utsunomiya K. Effect of hemodialysis on plasma glucose profile and plasma level of liraglutide in patients with type 2 diabetes mellitus and end-stage renal disease: a pilot study. PLoS One 2014;9(12):e113468.

Peters KR. Liraglutide for the treatment of type 2 diabetes: a clinical update. Am. J. Ther. 2013;20(2):178-88. [DOI: 10. 1097/MJT.0b013e3182204c16]

Prasad-Reddy L, Isaacs D. A clinical review of GLP-1 receptor agonists: efficacy and safety in diabetes and beyond. Drugs Context 2015;4:212283. [DOI: 10.7573/dic. 212283]

Qi L, Ke L, Liu X, Liao L, Ke S, Liu X, Wang Y, Lin X, Zhou Y, Wu L, Chen Z, Liu L. Subcutaneous administration of liraglutide ameliorates learning and memory impairment by modulating tau hyperphosphorylation via the glycogen synthase kinase-3beta pathway in an amyloid beta protein induced alzheimer disease mouse model. Eur. J. Pharmacol. 2016;783:23-32.

Rizvi AA, Patti AM, Giglio RV, Nikolic D, Amato A, Al-Busaidi N, Al-Rasadi K, Soresi M, Banach M, Montalto G, Rizzo M. Liraglutide improves carotid intima-media thickness in patients with type 2 diabetes and non-alcoholic fatty liver disease: an 8-month prospective pilot study. Expert Opin. Biol. Ther. 2015;15(10):1391-7.

Rizzo M, Rizvi AA, Patti AM, Nikolic D, Giglio RV, Castellino G, Volti GL, Caprio M, Montalto G, Provenzano V, Genovese $\mathrm{S}$, Ceriello A. Liraglutide improves metabolic parameters and carotid intima-media thickness in diabetic patients with the metabolic syndrome: an 18-month prospective study. Cardiovasc. Diabetol. 2016;15:162.

Russo GT, Labate AM, Giandalia A, Romeo EL, Villari P, Alibrandi A, Perdichizzi G, Cucinotta D. Twelve-month treatment with liraglutide ameliorates visceral adiposity index and common cardiovascular risk factors in type 2 diabetes outpatients. J. Endocrinol. Invest. 2015;38(1):819. [DOI: 10.1007/s40618-014-0163-9]

Ryuge A, Minoru K, Yu K, Takaya O, Masahiko Y, Makoto Y, Yukako O, Yoichiro H, Takahiro I, Tatsuhito T, Hideaki S, Eitaro N, Yoshiro F. Examination of the effects of liraglutide on diabetic nephropathy. Kidney Res. Clin. Prac. 2012;31(2):A70. [DOI: 10.1016/j.krcp.2012.04.536]

Salcedo I, Tweedie D, Li Y, Greig NH. Neuroprotective and neurotrophic actions of glucagon-like peptide-1: an emerging opportunity to treat neurodegenerative and cerebrovascular disorders. Br. J. Pharmacol. 2012;166(5): 1586-99. [DOI: 10.1111/j.1476-5381.2012.01971.x]
Schneider C, Coll B, Jick SS, Meier CR. Doubling of serum creatinine and the risk of cardiovascular outcomes in patients with chronic kidney disease and type 2 diabetes mellitus: a cohort study. Clin. Epidemiol. 2016;8:177-84.

Schwartz SS, Kohl BA. Glycemic control and weight reduction without causing hypoglycemia: the case for continued safe aggressive care of patients with type 2 diabetes mellitus and avoidance of therapeutic inertia. Mayo Clin. Proc. 2010;85(12):S15-S26.

Serhiyenko VA, Serhiyenko AA. Diabetic cardiac autonomic neuropathy: do we have any treatment perspectives? World J. Diabetes 2015;6:245-58. [DOI: 10.4239/wjd.v6.i 2.245]

Sharma S, Pathak S, Gupta G, Sharma SK, Singh L, Sharma RK, Mishra A, Dua K. Pharmacological evaluation of aqueous extract of syzigium cumini for its antihyperglycemic and antidyslipidemic properties in diabetic rats fed a high cholesterol diet-role of PPARgamma and PPARalpha. Biomed. Pharmacother. 2017;89:447-53. [DOI: 10.1016/j.biopha.2017.02.048]

Tabit CE, Chung WB, Hamburg NM, Vita JA. Endothelial dysfunction in diabetes mellitus: molecular mechanisms and clinical implications. Rev. Endocr. Metab. Disord. 2010; 11(1):61-74. [DOI: 10.1007/s11154-010-9134-4]

Tamasawa A, Saito M, Ishida H, Osonoi Y, Osonoi T. The renal protective effects of liraglutide in patients with type 2 diabetes and nephropathy: a retrospective observational study. Int. J. Diabetes Clin. Diagn. 2017;4:124. [DOI: 10.15344/2394-1499/2017/124]

Tan J, Zwi LJ, Collins JF, Marshall MR, Cundy T. Presentation, pathology and prognosis of renal disease in type 2 diabetes. BMJ Open Diabetes Res. Care 2017;5(1):e000412. [DOI: 10.1136/bmjdrc-2017-000412]

Thomas MC. The potential and pitfalls of GLP-1 receptor agonists for renal protection in type 2 diabetes. Diabetes Metab. 2017;43(1):2S20-7.

Tiwari J, Gupta G, Dahiya R, Pabreja K, Sharma RK, Mishra A, Dua K. Recent update on biological activities and pharmacological actions of liraglutide. Excli J. 2017;16: 742-7. [DOI: 10.17179/excli2017-323]

Van Buren PN, Toto R. Hypertension in diabetic nephronpathy: epidemiology, mechanisms, and management. Adv. Chronic Kidney Dis. 2011;18(1):28-41. [DOI: 10.1053/j.ac kd.2010.10.003]

Warren TY, Barry V, Hooker SP, Sui X, Church TS, Blair SN. Sedentary behaviors increase risk of cardiovascular disease mortality in men. Med. Sci. Sports Exerc. 2010; 42(5):879-85. [DOI: 10.1249/MSS.0b013e3181c3aa7e]

Yuan CM, Nee R, Ceckowski KA, Knight KR, Abbott KC. Diabetic nephropathy as the cause of end-stage kidney disease reported on the medical evidence form CM S2728 at a single center. Clin. Kidney J. 2017;10(2):25762. [DOI: 10.1093/ckj/sfw112]

Zhang W, Liu H, Al-Shabrawey M, Caldwell RW, Caldwell RB. Inflammation and diabetic retinal microvascular complications. J. Cardiovasc. Dis. Res. 2011;2(2):96-103. [DOI: 10.4103/0975-3583.83035]

Zhu H, Zhang Y, Shi Z, Lu D, Li T, Ding Y, Ruan Y, Xu A. The neuroprotection of liraglutide against ischaemia-induced apoptosis through the activation of the PI3K/AKT and MAPK pathways. Sci. Rep. 2016;6:26859. [DOI: 10.1038/s rep26859] 